\title{
Intertemporal and intratemporal consumption smoothing at retirement: micro evidence from detailed spending and time use data
}

\author{
Jim Been* and Kees Goudswaard \\ Department of Economics, Leiden University and Netspar, Leiden, The Netherlands \\ ${ }^{*}$ Corresponding author. Email: j.been@law.leidenuniv.nl
}

(Received 18 September 2020; revised 7 July 2021; accepted 7 July 2021; first published online 6 September 2021)

\begin{abstract}
Using detailed spending and time use data from the Netherlands, this paper analyzes the causal effect of retirement on spending and time use decisions. Both total consumption and disaggregated consumption categories are considered. We do not find empirical evidence for drops in households' total non-durable spending at retirement. Our estimates suggest increases in spending at retirement on goods that are complementary to leisure, but no decreases in spending on goods that are replaceable by home production. The quantitative implication of our empirical results for the Life-Cycle Model is an intertemporal elasticity of substitution for leisure below unity.
\end{abstract}

Keywords: Consumption; panel data; regression discontinuity; retirement; time use

JEL-codes: C33; D1; H55; J22; J26

\section{Introduction}

Consumption smoothing at retirement has been empirically assessed in a wide variety of countries. Studies focusing on American households ${ }^{1}$ and British households ${ }^{2}$ unanimously find substantial drops in consumption at retirement varying from $10 \%$ to $20 \%$. Such a consumption drop has long been thought to be at odds with the predictions of the seminal Life-Cycle Model (LCM) of Ando and Modigliani (1963) and was, therefore, known as the Retirement Consumption Puzzle (RCP). Existing empirical evidence from European households is scarcer and shows more mixed results. French, Italian, and Spanish households do not show changes in total consumption at retirement. ${ }^{3}$ In contrast to these European countries, substantial drops in spending at retirement are observed in Germany. ${ }^{4}$

Drops in spending at retirement are not inconsistent with the LCM per se, because households may not smooth consumption, but the marginal utility of consumption. First, there may be strong consumption-leisure complementarities (Laitner and Silverman, 2005). Empirical evidence from Aguiar and Hurst (2009) suggests that the change in spending among US households is largely due to the complementarities of these spending categories with work time and leisure. Second, building

\footnotetext{
${ }^{1}$ For example, Bernheim et al. (2001); Laitner and Silverman (2005); Aguiar and Hurst (2005); Hurd and Rohwedder (2005, 2006); Haider and Stephens (2007); Blau (2008); Fisher et al. (2008); Hurst (2008); Aguila et al. (2011); Laitner and Silverman (2012); Been et al. (2021).

${ }^{2}$ For example, Banks et al. (1998); Smith (2006).

${ }^{3}$ For example, Moreau and Stancanelli (2015); Battistin et al. (2009); Luengo-Prado and Sevilla (2012).

${ }^{4}$ For example, Luhrmann (2010).

(c) The Author(s), 2021. Published by Cambridge University Press. This is an Open Access article, distributed under the terms of the Creative Commons Attribution licence (http://creativecommons.org/licenses/by/4.0/), which permits unrestricted re-use, distribution and reproduction, provided the original article is properly cited.
} 
on the seminal work of Becker (1965), spending may be replaced by home production at retirement (Hurst, 2008). For both US households ${ }^{5}$ and German households, ${ }^{6}$ studies find substantial increases in home production next to substantial decreases in spending at retirement. Despite the absence of substantial spending drops, French, Italian, and Spanish households also show substantial increases in home production at retirement. ${ }^{7}$ This raises the question to what extent spending and time use decisions interact at retirement and, more specifically, if more smoothing of consumption over time (i.e., intertemporal substitution) implies lower substitution between spending and home production (i.e., intratemporal substitution) and vice versa.

We provide new empirical evidence on this question by estimating the causal effects of retirement on a wide array of consumption spending and time categories available in a single longitudinal sample. Aforementioned studies have largely remained impartial in their analyses by either analyzing spending or time use decisions. Aguiar and Hurst (2005) are the first to consider both spending and home production, but only focus on food-related categories. Luengo-Prado and Sevilla (2012) use broader definitions of both spending and time use of Spanish households, but for different samples of the population. Moreover, their estimates of the effect of retirement cannot be interpreted causally, because they lack panel data and a discontinuity in retirement policies. In this paper, we use unique micro level panel data of Dutch households from LISS with information on 21 spending and 13 time use categories. The Netherlands is an interesting case, because the Dutch pension system is relatively generous and there has been no prior causal evidence on this topic for the Netherlands.

Using both a fuzzy Regression Discontinuity (RD), like Stancanelli and Van Soest (2012), and the panel nature of the data, like Luengo-Prado and Sevilla (2012), we analyze the causal effects of retirement on households' spending and time use in home production and leisure. These effects are important inputs in the LCM of Rogerson and Wallenius (2016). This simple LCM allows us to draw conclusions regarding the ratio of the intertemporal elasticity of substitution for leisure and the elasticity of substitution between time and goods in home production. The literature commonly assumes that this ratio is well over one (Rogerson and Wallenius, 2016). Using disaggregate categories of spending and time use related to the substitution between home production and spending, we are able to identify the size of the elasticity of substitution between time and goods in home production and, hence, about the intertemporal elasticity of substitution for leisure. Additionally, analyzing disaggregate categories of spending and time use allows us to determine the extent to which retirees increase leisure-complementary spending.

Given our empirical results, we do not find a significant drop in total consumption spending at retirement among Dutch households. However, we find substantial increases in home production upon retirement as large as 6.5 hours per week (increase of 47\%). These patterns are consistent with prior empirical evidence from European countries. ${ }^{8}$ The increase in home production is at odds with the lack of a spending drop if home production is to smooth consumption at retirement.

Analyzing disaggregate categories of spending, we do not find decreases in spending categories that can be replaced by home production, such as cleaning and food out. This suggests that retirees do not replace spending categories, but increase home production without replacing spending instead. Hence, the increase in time spent on home production is most likely a consequence of increased non-work time available at retirement. We also find substantial increases in leisure time upon retirement as large as 14 hours per week (increase of 38\%). Our analysis of disaggregate spending categories shows a shift toward leisure-complementary consumption, such as vacations, at retirement. This likely explains the (non-statistically significant) increase in total spending at retirement. The lack of a drop in

\footnotetext{
${ }^{5}$ Aguiar and Hurst (2005); Hurd and Rohwedder (2007); Hurst (2008); Been et al. (2020, 2021).

${ }^{6}$ Schwerdt (2005); Luhrmann (2010); Velarde and Herrmann (2014); Bonsang and Van Soest (2020).

${ }^{7}$ Ciani (2016); Stancanelli and Van Soest (2012); Luengo-Prado and Sevilla (2012).

${ }^{8}$ Moreau and Stancanelli (2015); Battistin et al. (2009); Luengo-Prado and Sevilla (2012); Stancanelli and Van Soest (2012); Ciani (2016).
} 
total spending, increases in home production, and increases in leisure-complementary spending suggest that retirement might even increase well-being.

Using our estimates in the LCM of Rogerson and Wallenius (2016), we find that the ratio of the intertemporal elasticity of substitution for leisure and the intratemporal elasticity of substitution between time and goods in home production is about 0.82 . This ratio is comparable to the ratio that Rogerson and Wallenius (2016) find for US households (0.92) and confirm that this ratio is close to one. However, US households are confronted with substantial drops in spending at retirement while Dutch households are not. Additionally, our empirical results strongly suggest the absence of intratemporal smoothing among Dutch households. Therefore, we conclude that an elasticity of intertemporal substitution of leisure below unity is mostly in line with our empirical evidence. ${ }^{9}$ Although the ratios are of similar magnitude, comparing the Dutch evidence to the US evidence from Rogerson and Wallenius (2016) suggests that it is likely that the ratio of US households is driven by both (1) a larger intertemporal elasticity of substitution for leisure (hence, the drop in spending) and (2) a larger intratemporal elasticity of substitution between time and goods in home production (hence, increases (decreases) in home production (eating out)).

\section{Data}

\subsection{Institutional framework of the Netherlands}

This paper exploits detailed consumption spending and time use data from the Netherlands. In the Netherlands, households receive relatively generous public pensions at retirement and face high mandatory savings through occupational pensions. As in many European countries, the Dutch pension system consists of three pillars. The first is a pay-as-you-go system and involves a flat-rate public pension benefit for all residents as from the statutory retirement age (SRA). Prior to 2013, this SRA was set at age 65 and was the same for everyone. As of January 1, 2013, the SRA has been gradually increased. For details of the SRA for the different cohorts, we refer to Table 1. Those who would have been within 2 years of their SRA in the old regime only had about 3.5-6.5 months to adjust their behavior between the announcement of the reform and the reform taking effect. ${ }^{10}$

Flexible take-up of the state pension, either before or after the SRA, is not possible in the Netherlands. This is in contrast with the US where benefits can be claimed before and after the full retirement age as long as benefits are claimed from the age of 62 and no later than the age of 70 (Duggan et al., 2007). The second pillar consists of capital-funded occupational pensions, of which the primary responsibility lies with employers and employees. Around $90 \%$ of all employees have a mandatory pension scheme with their employer. The third pillar is formed by private individual pension products (such as life annuities) and other private savings. Knoef et al. (2016) analyze Dutch pension savings using a large administrative dataset. When only public and occupational pensions are considered (on average roughly two-third of total wealth), Knoef et al. (2016) find a median net replacement rate of $84 \%$. When private pensions, private savings, and housing wealth are also included, they find a median net replacement rate of roughly $100 \%$. The authors stress that there is a lot of heterogeneity in pension income at retirement, but mostly in absolute levels (euros) and less so in (net) replacement rates.

\subsection{LISS data}

We use data from the LISS panel (Longitudinal Internet Studies for the Social sciences) administered by CentERdata at Tilburg University. The annual core waves consist of 5,000 representative households (about 8,000 individuals) in the Netherlands. These households are followed over the time

\footnotetext{
${ }^{9}$ This finding is consistent with prior evidence for the Netherlands from Kapteyn and Teppa (2003), although our estimate is closer to unity.

${ }^{10}$ The change in the law was submitted on July 12, 2012. The Netherlands Ministry of Social Affairs communicated the change in the law as of September 17, 2012. The change took effect on January 1, 2013.
} 
Table 1. Step-wise increase of the statutory retirement age as introduced in 2013

\begin{tabular}{llr}
\hline Birth date & Statutory retirement age & Obs. \\
\hline $\begin{array}{l}\text { Before January 1, 2013 } \\
\text { All birth dates }\end{array}$ & 65 & 5,035 \\
As of January 1, 2013 & 65 & 1,379 \\
$\quad$ <January 1, 1948 & $65+1$ month & 417 \\
January 1, 1948-November 30, 1948 & $65+2$ months & 481 \\
December 1, 1948-October 31, 1949 & $65+3$ months & 467 \\
November 1, 1949-September 30, 1950 & $65+6$ months & 324 \\
October 1, 1950-June 30, 1951 & $65+9$ months & 335 \\
July 1, 1951-March 31, 1952 & 66 & 320 \\
April 1, 1952-December 31, 1952 & $66+4$ months & 290 \\
January 1, 1953-August 31, 1953 & $66+8$ months & 299 \\
September 1, 1953-April 30, 1954 & 67 & 140 \\
May 1, 1954-December 31, 1955 & $67+3$ months & 2,585 \\
December 31, 1955 & & \\
\hline
\end{tabular}

period 2008-2019. The LISS Background Variables were supplemented with an additional module on Time Use and Consumption in the 2009, 2010, 2012, 2015, 2017, and 2019 waves and an additional module on Economics Assets related to Income in the 2008-2019 waves. The Time Use and Consumption module is used by, among others, Cherchye et al. $(2012,2017)$ and Boerma and Karabarbounis (2019).

For the empirical analysis, we select only household heads ${ }^{11}$ following Aguiar and Hurst (2005) and keep those household heads aged $55-75^{12}$ who report not to depend on unemployment or sickness/ disability benefits. ${ }^{13},{ }^{14}$ Household heads are the main income earner in multiple-member households. Following prior analyses by, e.g., Aguiar and Hurst (2005), Aguila et al. (2011), and Luengo-Prado and Sevilla (2012), we leave any interaction in time use decisions between spouses, as analyzed by Rogerson and Wallenius (2019), for future research but explicitly take into account the different structures of the households in the sensitivity analysis. Using only household heads reduces issues regarding withinhousehold interactions.

Table A1 provides summary statistics of the variables used in the empirical analysis. Moreover, it indicates the availability of variables in the different years of the LISS panel. The Time Use and Consumption survey considers spending categories at the household level (e.g., mortgage, utilities, etc.) and spending categories for personal use and children (e.g., clothing, personal care, etc.). Note that the LISS Time Use and Consumption data only consider non-durable consumption spending. We construct households' personal spending categories by adding these categories up to the household level. We construct total (non-durable) household spending by adding up all categories, householdand personal spending, to the household level. We set missing observations in spending categories to zero for those households who reported at least total household spending (which is asked after all the separate categories - see Appendix A). This assumes that respondents who reported total spending but did not respond to a particular category have zero expenditures in this category despite explicitly being asked to enter a zero in such cases. This approach ensures the same number of observations in all household spending categories. We do the same for personal spending categories.

\footnotetext{
${ }^{11}$ This reduces the number of observations from 65,888 in the raw data to 45,136. Additionally, we delete those households whose household head changed over time to make sure we keep tracking the same person in the household. This reduces the number of observations to 42,457 .

${ }^{12}$ This reduces our number of observations further from 42,457 to 14,322 . In Table 2, we present results that use a tighter age-window from 60 to 70 and show that the main conclusions hold.

${ }^{13}$ This reduces our number of observations from 14,322 to 12,597 . This selection is important as our analysis indicates that this subsample increases consumption spending at retirement (not reported here) which is likely due to budget constraints in unemployment and disability prior to retirement.

${ }^{14}$ These 12,597 observations imply 6,257 observations for the years in which the Time Use and Consumption component is available.
} 
However, the number of observations per personal spending category can be different as the disaggregated categories are only available in the 2009, 2010, and 2012 waves. Nonetheless, the aggregate of total personal spending is asked in every wave.

Time use categories are either available in all waves (like paid work and commuting) or are missing in 2015 and 2017 waves (like home production and leisure time). We refer to Appendix A for details on the survey questions asked to the respondents.

Although the LISS data are only one of two longitudinal data sets (the other being HRS/CAMS) with information on spending and time use categories that go beyond food spending and cooking, it has two main shortcomings. First, both spending and time use are recall data and are not elicited through spending- and time-diaries. This may introduce some recall bias in the responses. However, it is unlikely that such a recall bias will introduce substantial biases in our analyses. In the case of $\mathrm{RD}$, the recall bias does not induce any problems as long as it is, on average, similar to those right before and those right after the discontinuity. In the case of FE, the recall bias does not induce any problems as long as this recall bias is consistent within individuals over time. Second, given that the LISS is a general-purpose survey, there were limits on the level of detail and, hence, survey time that could be spent on eliciting time use and spending. The categorization of the data in 21 spending and 13 time use categories may mean that we miss some relevant categories as well as subtleties within these categories. The first may mean that we miss some relevant categories of home production, leisure, and substitutable or complementary spending which leads to an underestimation of the interactions. The latter means that our analysis conceals some shifts within spending categories at retirement, such as work clothing (decreases) versus leisure clothing (increases). Lastly, the data's level of detail is such that we cannot distinguish between the consumption and leisure components of home production. We, therefore, assume that home production does not include a leisure component (i.e., gardening can be considered a hobby for some). For discussions, see Pollak and Watcher (1975) and Kerkhofs and Kooreman (2003). Due to the limited level of detail of the data, we may not capture all the subtleties in the changing compositions of spending and time use at retirement.

\subsection{Discontinuities at the retirement age}

Our empirical methodology, as outlined in Section 3.2, assumes that retirement is induced by the institutionally set SRA which is cohort-specific as of January 2013. This implies that there should be a discontinuous jump in the probability of retirement upon reaching the SRA.

Prior evidence has shown that households are very responsive to the (change in) institutional retirement age which causes a discontinuous probability in retirement right before and right after reaching the SRA. ${ }^{15}$ This includes evidence specific to the Netherlands. ${ }^{16}$ In the Netherlands, people have a strong incentive to retire at the (non-flexible) SRA, because it provides a substantial amount of total available pension income (Knoef et al., 2016). Retiring earlier than the SRA implies that one does not receive state pension benefits up to reaching the SRA. Early retirement schemes have been abolished as of 2005 which has made retirement before the SRA very unattractive. Retiring later than the SRA does not actuarially increase the state pension benefits. Graphical evidence of the discontinuous probability to retire at the SRA is provided in Figure 1.

As of 2013, we observe the exact date at which respondents are eligible for state pensions according to the reform. We base the SRA of the respondents on this information. This allows us to study age in months. However, we have no information on the exact birth data prior to 2013. Since the panel is unbalanced, measuring age in months instead of years decreases the number of observations. Therefore, we present age measured in years in our baseline $\mathrm{RD}$ and show that results are robust to different measures of age and the cutoff-point in Table 2. First, results are robust to using the fixed

\footnotetext{
${ }^{15}$ Duggan et al. (2007); Mastrobuoni (2009); Behaghel and Blau (2012).

${ }^{16}$ De Grip et al. (2013); Van Erp et al. (2014); Vermeer (2016); Atav et al. (2019); Piccheo and Van Ours (2019); Nagore Garcia et al. (2021).
} 
Table 2. Sensitivity to sample and definitions of retirement

\begin{tabular}{|c|c|c|c|c|c|c|c|c|c|c|c|c|c|}
\hline & & & \multicolumn{7}{|c|}{ Spending } & \multicolumn{4}{|c|}{ Time use } \\
\hline & & & Transport & Cleaning & Food in & Holiday & Food out & Leisure & Total & Work & Commute & Home & Leisure \\
\hline \multirow[t]{2}{*}{ HP-sample } & $\mathrm{RD}$ & $\begin{array}{l}\text { Coeff. } \\
\text { SE }\end{array}$ & $\begin{array}{c}-21.611 \\
(18.418)\end{array}$ & $\begin{array}{l}14.008 \\
(9.935)\end{array}$ & $\begin{array}{l}98.659^{\star \star \star} \\
(35.155)\end{array}$ & $\begin{array}{l}63.541^{\star \star} \\
(29.494)\end{array}$ & $\begin{array}{c}12.613 \\
(13.354)\end{array}$ & $\begin{array}{c}10.610 \\
(14.616)\end{array}$ & $\begin{array}{c}148.520 \\
(181.984)\end{array}$ & $\begin{array}{c}-28.000^{\star \star \star} \\
(2.081)\end{array}$ & $\begin{array}{l}-3.508^{\star \star \star} \\
(0.533)\end{array}$ & $\begin{array}{l}6.598^{\star \star \star} \\
(1.847)\end{array}$ & $\begin{array}{l}13.801^{\star \star \star} \\
(3.496)\end{array}$ \\
\hline & & $N$ & 3,635 & 3,635 & 3,635 & 3,635 & 2,686 & 2,686 & 3,635 & 3,637 & 3,654 & 3,676 & 3,619 \\
\hline \multirow[t]{2}{*}{$60-70$} & $\mathrm{RD}$ & $\begin{array}{l}\text { Coeff. } \\
\text { SE }\end{array}$ & $\begin{array}{l}-1.039 \\
(23.255)\end{array}$ & $\begin{array}{l}19.684^{\star} \\
(11.558)\end{array}$ & $\begin{array}{c}56.048 \\
(42.544)\end{array}$ & $\begin{array}{c}40.439 \\
(34.137)\end{array}$ & $\begin{array}{l}-0.879 \\
(47.409)\end{array}$ & $\begin{array}{c}30.440 \\
(53.005)\end{array}$ & $\begin{array}{c}154.788 \\
(216.902)\end{array}$ & $\begin{array}{c}-22.241^{\star \star \star} \\
(2.748)\end{array}$ & $\begin{array}{c}-2.357^{\star \star \star} \\
(0.635)\end{array}$ & $\begin{array}{c}1.981 \\
(3.674)\end{array}$ & $\begin{array}{l}13.398^{\star \star} \\
(6.812)\end{array}$ \\
\hline & & $N$ & 4,215 & 4,215 & 4,215 & 4,215 & 1,928 & 1,928 & 4,215 & 4,202 & 4,206 & 2,614 & 2,595 \\
\hline \multirow[t]{2}{*}{ Donut $(|A|>1)$} & $\mathrm{RD}$ & $\begin{array}{l}\text { Coeff. } \\
\text { SE }\end{array}$ & $\begin{array}{l}-8.819 \\
(19.245)\end{array}$ & $\begin{array}{r}5.568 \\
(10.507)\end{array}$ & $\begin{array}{c}49.298 \\
(36.439)\end{array}$ & $\begin{array}{r}53.160^{*} \\
(29.583)\end{array}$ & $\begin{array}{c}20.768 \\
(18.069)\end{array}$ & $\begin{array}{c}20.792 \\
(20.167)\end{array}$ & $\begin{array}{c}132.120 \\
(180.938)\end{array}$ & $\begin{array}{c}-26.009^{\star * *} \\
(1.981)\end{array}$ & $\begin{array}{l}-2.704^{\star \star *} \\
(0.481)\end{array}$ & $\begin{array}{l}7.068^{\star * *} \\
(2.678)\end{array}$ & $\begin{array}{l}10.337^{\text {** }} \\
(4.674)\end{array}$ \\
\hline & & $N$ & 4,823 & 4,823 & 4,823 & 4,823 & 2,155 & 2,155 & 4,823 & 4,772 & 4,790 & 2,998 & 2,972 \\
\hline \multirow[t]{2}{*}{ Work hours } & $\mathrm{RD}$ & $\begin{array}{l}\text { Coeff. } \\
\text { SE }\end{array}$ & $\begin{array}{c}0.341 \\
(0.523)\end{array}$ & $\begin{array}{r}-0.061 \\
(0.267)\end{array}$ & $\begin{array}{c}-2.201^{\star \star} \\
(0.980)\end{array}$ & $\begin{array}{c}-1.273 \\
(0.807)\end{array}$ & $\begin{array}{c}-0.414 \\
(0.523)\end{array}$ & $\begin{array}{c}-0.408 \\
(0.564)\end{array}$ & $\begin{array}{c}-4.104 \\
(4.835)\end{array}$ & $\begin{array}{l}1.000^{\star \star \star} \\
(0.000)\end{array}$ & $\begin{array}{l}0.122^{\star \star \star} \\
(0.012)\end{array}$ & $\begin{array}{l}-0.228^{\star \star \star} \\
(0.064)\end{array}$ & $\begin{array}{l}-0.456^{\star \star \star} \\
(0.117)\end{array}$ \\
\hline & & $N$ & 5,701 & 5,701 & 5,701 & 5,701 & 2,677 & 2,677 & 5,701 & 5,769 & 5,742 & 3,637 & 3,612 \\
\hline \multirow[t]{2}{*}{ Full retirement } & $\mathrm{RD}$ & $\begin{array}{l}\text { Coeff. } \\
\text { SE }\end{array}$ & $\begin{array}{l}-5.128 \\
(15.770)\end{array}$ & $\begin{array}{c}5.398 \\
(8.176)\end{array}$ & $\begin{array}{l}69.653^{\star \star} \\
(29.958)\end{array}$ & $\begin{array}{l}49.101^{\star *} \\
(24.490)\end{array}$ & $\begin{array}{c}12.849 \\
(14.073)\end{array}$ & $\begin{array}{c}14.597 \\
(15.442)\end{array}$ & $\begin{array}{c}203.561 \\
(147.101)\end{array}$ & $\begin{array}{c}-30.531^{\star \star \star} \\
(1.795)\end{array}$ & $\begin{array}{l}-3.640^{\star \star \star} \\
(0.395)\end{array}$ & $\begin{array}{l}7.116^{\star \star \star} \\
(2.072)\end{array}$ & $\begin{array}{l}15.706^{\star \star \star} \\
(3.888)\end{array}$ \\
\hline & & $N$ & 5,815 & 5,815 & 5,815 & 5,815 & 751 & 2,751 & 5,815 & 5,769 & 5,787 & 3,676 & 3,651 \\
\hline \multirow[t]{2}{*}{ Paid work } & $\mathrm{RD}$ & $\begin{array}{l}\text { Coeff. } \\
\text { SE }\end{array}$ & $\begin{array}{l}-1.954 \\
(13.534)\end{array}$ & $\begin{array}{c}0.532 \\
(6.935)\end{array}$ & $\begin{array}{l}44.226^{\star} \\
(25.187)\end{array}$ & $\begin{array}{c}33.197 \\
(20.709)\end{array}$ & $\begin{array}{c}9.716 \\
(13.156)\end{array}$ & $\begin{array}{c}5.934 \\
(14.065)\end{array}$ & $\begin{array}{c}74.404 \\
(123.853)\end{array}$ & $\begin{array}{c}-30.022^{\star \star \star} \\
(1.194)\end{array}$ & $\begin{array}{l}-4.055^{\star \star \star} \\
(0.344)\end{array}$ & $\begin{array}{l}6.414^{\star \star \star} \\
(1.579)\end{array}$ & $\begin{array}{l}13.422^{\star \star \star} \\
(3.116)\end{array}$ \\
\hline & & $N$ & 4,774 & 4,774 & 4,774 & 4,774 & 2,238 & 2,238 & 4,774 & 4,755 & 4,747 & 2,985 & 2,959 \\
\hline \multirow[t]{2}{*}{$\mathrm{SRA}=65$} & $\mathrm{RD}$ & $\begin{array}{l}\text { Coeff. } \\
\text { SE }\end{array}$ & $\begin{array}{c}5.837 \\
(15.930)\end{array}$ & $\begin{array}{c}4.071 \\
(8.211)\end{array}$ & $\begin{array}{l}92.646^{\star \star *} \\
(30.211)\end{array}$ & $\begin{array}{l}65.292^{\star * \star} \\
(24.824)\end{array}$ & $\begin{array}{c}11.746 \\
(13.160)\end{array}$ & $\begin{array}{c}12.177 \\
(14.357)\end{array}$ & $\begin{array}{c}216.923 \\
(148.485)\end{array}$ & $\begin{array}{c}-26.190^{\star \star \star} \\
(1.769)\end{array}$ & $\begin{array}{l}-2.928^{\star \star \star} \\
(0.405)\end{array}$ & $\begin{array}{l}7.002^{\star \star \star *} \\
(2.216)\end{array}$ & $\begin{array}{l}15.790^{\star \star \star} \\
(4.106)\end{array}$ \\
\hline & & $N$ & 5,815 & 5,815 & 5,815 & 5,815 & 2,751 & 2,751 & 5,815 & 5,769 & 5,787 & 3,676 & 3,651 \\
\hline \multirow[t]{2}{*}{$\begin{array}{l}\text { Year<2013 } \\
(\text { SRA }=65)\end{array}$} & $\mathrm{RD}$ & $\begin{array}{l}\text { Coeff. } \\
\text { SE }\end{array}$ & $\begin{array}{l}-8.667 \\
(21.143)\end{array}$ & $\begin{array}{c}7.210 \\
(10.111)\end{array}$ & $\begin{array}{l}115.826^{\star \star *} \\
(41.479)\end{array}$ & $\begin{array}{l}78.119 * * \\
(34.644)\end{array}$ & $\begin{array}{c}11.746 \\
(13.160)\end{array}$ & $\begin{array}{c}12.177 \\
(14.357)\end{array}$ & $\begin{array}{c}101.110 \\
(200.845)\end{array}$ & $\begin{array}{c}-25.854^{\star \star *} \\
(2.357)\end{array}$ & $\begin{array}{l}-3.957^{\star \star \star *} \\
(0.584)\end{array}$ & $\begin{array}{l}6.450^{\star \star *} \\
(2.019)\end{array}$ & $\begin{array}{l}15.084^{\star \star \star *} \\
(3.862)\end{array}$ \\
\hline & & $N$ & 2,821 & 2,821 & 2,821 & 2,821 & 2,751 & 2,751 & 2,821 & 2,765 & 2,784 & 2,777 & 2,758 \\
\hline \multirow[t]{2}{*}{ Age in months } & $\mathrm{RD}$ & $\begin{array}{l}\text { Coeff. } \\
\text { SE }\end{array}$ & $\begin{array}{c}9.218 \\
(17.940)\end{array}$ & $\begin{array}{c}-2.581 \\
(8.808)\end{array}$ & $\begin{array}{c}37.178 \\
(31.290)\end{array}$ & $\begin{array}{c}28.838 \\
(27.013)\end{array}$ & $\begin{array}{c}-30.476 \\
(27.501)\end{array}$ & $\begin{array}{l}-86.646^{\star \star} \\
(36.007)\end{array}$ & $\begin{array}{l}-18.935 \\
(152.934)\end{array}$ & $\begin{array}{c}-28.950^{\star \star \star} \\
(1.972)\end{array}$ & $\begin{array}{l}-4.009^{\star \star \star} \\
(0.412)\end{array}$ & $\begin{array}{l}6.014^{\star \star} \\
(2.573)\end{array}$ & $\begin{array}{l}13.477^{\star \star \star} \\
(4.622)\end{array}$ \\
\hline & & $N$ & 4,123 & 4,123 & 4,123 & 4,123 & 1,520 & 1,520 & 4,123 & 4,095 & 4,112 & 2,216 & 2,203 \\
\hline
\end{tabular}

${ }^{*}$ Significant at the $10 \%$ level, ${ }^{* \star}$ at the $5 \%$ level, and ${ }^{* \star *}$ at the $1 \%$ level. Amounts are expressed in 2015 euros. Control variables are included. 


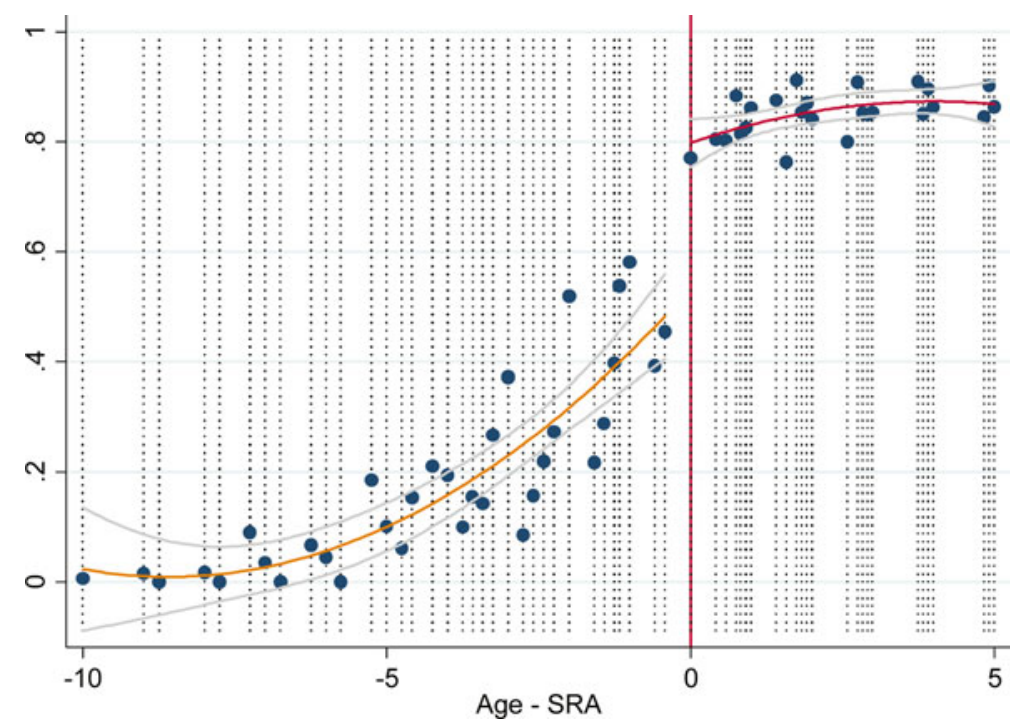

Figure 1. Retirement (fraction) by age minus statutory retirement age. ${ }^{25}$ Notes: Lower- and upper bounds of the $95 \%$ interval are presented in light gray lines.

age of 65 as a cutoff-point (Table 2). In Appendix E we show that the age of 65 remains an important point of reference for the expected retirement age consistent with Vermeer et al. (2019) who find strong anchoring of retirement behavior at the age of 65 . This is confirmed by only using the period prior to 2013 in the analysis in which 65 was the SRA for all respondents (Table 2). Second, using age measured in months does not alter our main conclusions (Table 2). In Appendix E we show that much of the bunching of retirement age expectations takes place at age 65,67, and 68 which means that the exact identification of months between 65 and 67 may be of little importance. Third, using approaches that are less vulnerable to details of age and cutoff measures, such as 'donut' RD (Table 2) and Fixed Effects (FE) regression (Tables 3-5), does not alter our main conclusions.

In Figure 1, we observe that the percentage of respondents that is retired is about 30\%-points higher at the SRA than prior to reaching the SRA. Ninety-five percent confidence intervals are shown and suggest that the jump is statistically significant. Although the percentage of retirees increases over age, this year-to-year increase is never bigger than upon reaching the SRA. This visual evidence indicates that Dutch households are responsive to the SRA. However, not all persons are retired after the SRA. After reaching the SRA, we observe that about $20 \%$ of the respondents have not yet retired. ${ }^{17}$ Since the state pension only provides a minimum substance level, some people want to continue working after the retirement age, especially if their occupational pension income is low. Others may want to keep working, because of non-financial reasons. Dutch labor law allows people to work after the SRA with the main benefit that these workers no longer have to pay pension contributions and, thus, have a lower total tax burden.

In Figures 2-4, we show people's responses in total spending, home production, and leisure upon reaching the SRA. Ninety-five percent confidence intervals are presented to give an impression of the statistical significance of the change upon reaching the SRA. In Figure 2, the results suggest that there is no significant change in the level of total spending (in euros per month) at the SRA (confidence intervals before and after the SRA overlap). This visual evidence corroborates the LCM which suggests that agents smooth consumption over the life-cycle. Similarly, the graphical evidence in Table 4 suggests that home production (in hours per week) does not significantly increase at the SRA. Only leisure

\footnotetext{
${ }^{17}$ Thirteen percent reports to be in paid employment, $5 \%$ reports to perform voluntary work. The remaining people report to do something else, including taking care of the housekeeping.
} 
Table 3. Estimation results of the effect of retirement on household spending

Household consumption spending categories (euros/month) $-N=5,815$

\begin{tabular}{|c|c|c|c|c|c|c|c|c|c|c|c|c|c|c|c|}
\hline & & \\
\hline & & Mortgage & Rent & Utilities & Transport & Insurance & Alimony & Debt & Cleaning & Food & Daycare & Vacation & Other_hh ${ }^{a}$ & Total_hh ${ }^{b}$ & Total $^{c}$ \\
\hline \multirow[t]{2}{*}{ Pre-retire } & Mean & 317.559 & 124.217 & 203.839 & 130.465 & 218.646 & 22.770 & 25.325 & 40.924 & 326.14 & 0.276 & 119.491 & 96.292 & $1,629.207$ & $2,020.926$ \\
\hline & SD & $(408.536)$ & $(234.371)$ & (120.064) & $(126.200)$ & (171.067) & (88.944) & $(84.435)$ & $(60.057)$ & $(228.587)$ & (7.129) & (191.090) & $(136.076)$ & $(1,042.278)$ & $(1,220.799)$ \\
\hline \multirow[t]{2}{*}{ OLS } & Coeff. & 1.772 & -1.862 & 2.637 & -4.073 & 10.613 & -3.376 & -0.195 & -0.822 & 10.899 & 0.162 & $13.759^{\star}$ & 6.294 & -19.340 & -2.029 \\
\hline & SE & (17.154) & (12.046) & (5.386) & $(5.431)$ & $(6.858)$ & $(3.321)$ & $(2.837)$ & $(2.601)$ & (9.618) & $(0.127)$ & (7.878) & $(5.546)$ & $(44.320)$ & $(49.077)$ \\
\hline \multirow[t]{2}{*}{$\mathrm{RD}$} & Coeff. & -11.779 & 38.464 & 3.675 & -5.315 & -17.505 & $-22.997^{\star \star}$ & -13.628 & 3.717 & $61.129^{\star \star}$ & 0.807 & $42.940^{\star *}$ & -4.357 & 150.530 & 163.361 \\
\hline & SE & $(44.439)$ & $(30.077)$ & (14.313) & $(14.180)$ & (19.438) & $(8.972)$ & $(8.763)$ & (7.334) & $(26.725)$ & $(0.863)$ & (21.839) & (17.913) & $(112.712)$ & (132.002) \\
\hline \multirow[t]{2}{*}{ FE } & Coeff. & 0.326 & $-12.443^{\star}$ & $12.878^{\star \star}$ & 5.070 & 7.898 & 1.664 & -1.721 & -0.438 & $31.680^{\star \star \star}$ & 0.812 & $27.571^{\star \star \star}$ & -1.973 & $90.955^{*}$ & 92.779 \\
\hline & SE & $(16.349)$ & $(6.540)$ & (6.362) & (6.309) & (9.518) & $(4.810)$ & $(4.417)$ & (3.324) & (11.365) & $(0.714)$ & (9.134) & (8.124) & $(46.537)$ & (54.198) \\
\hline
\end{tabular}

*Significant at the $10 \%$ level, ${ }^{* *}$ at the $5 \%$ level, and ${ }^{* \star *}$ at the $1 \%$ level. Amounts are expressed in 2015 euros. Control variables are included.

aOther types of household consumption spending categories.

bThe total of household consumption spending categories.

cIncludes the total of household consumption spending categories and the total of personal consumption spending categories summed to the household level. 
Table 4. Estimation results of the effect of retirement on personal spending at the household level

\begin{tabular}{|c|c|c|c|c|c|c|c|c|c|c|c|}
\hline & & \multicolumn{10}{|c|}{ Personal consumption spending categories at $\mathrm{HH}$ level (euros/month) $-N=5,493$ (total), 2,751 (cats) } \\
\hline & & Food out & Tobacco & Clothes & Pers care & Med care & Leisure & School & Donation & Other & Total \\
\hline \multirow[t]{2}{*}{ Pre-retire } & Mean & 61.859 & 21.670 & 105.434 & 45.401 & 31.622 & 59.030 & 9.639 & 55.163 & 17.841 & 370.272 \\
\hline & SD & (84.743) & (46.732) & (119.224) & $(46.453)$ & (47.132) & $(74.765)$ & (35.819) & (62.819) & $(35.401)$ & (388.228) \\
\hline \multirow[t]{2}{*}{ OLS } & Coeff. & 0.205 & -4.534 & -0.113 & 3.687 & 2.640 & $14.086^{\star \star \star *}$ & -1.450 & 0.323 & $3.705^{\star \star}$ & 12.297 \\
\hline & SE & (4.454) & $(2.829)$ & $(6.390)$ & $(2.656)$ & (3.072) & $(4.316)$ & $(1.662)$ & (4.122) & $(1.831)$ & (13.270) \\
\hline \multirow[t]{2}{*}{$\mathrm{RD}$} & Coeff. & 12.177 & 1.016 & 15.435 & 10.037 & 1.547 & 11.746 & $-9.984^{\star}$ & -15.979 & 2.498 & -23.251 \\
\hline & SE & $(14.357)$ & (8.406) & (19.038) & $(8.221)$ & (9.046) & $(13.160)$ & $(5.180)$ & (11.274) & $(6.370)$ & (45.257) \\
\hline \multirow[t]{2}{*}{$\mathrm{FE}$} & Coeff. & -10.546 & 0.295 & 2.596 & 2.111 & 3.901 & 11.761 & -2.141 & 4.245 & $10.083^{\star \star}$ & -7.951 \\
\hline & SE & (8.031) & $(2.836)$ & $(10.093)$ & (3.832) & (4.744) & (8.458) & (4.385) & (8.283) & $(4.959)$ & (19.835) \\
\hline
\end{tabular}

*Significant at the $10 \%$ level, ${ }^{* *}$ at the $5 \%$ level, and ${ }^{* * \star}$ at the $1 \%$ level. Amounts are expressed in 2015 euros. Control variables are included. 
Table 5. Estimation results of the effect of retirement on time use

Personal time use (hours/week)

\begin{tabular}{|c|c|c|c|c|c|c|c|c|c|c|c|c|c|}
\hline & & Work & Commute & Home & Pers care & Childcare & $\begin{array}{c}\text { Care } \\
\text { parents }\end{array}$ & Care family & Care other & Leisure & School & Admin & Rest \\
\hline \multirow[t]{2}{*}{ Pre-retire } & Mean & 25.075 & 3.267 & 14.030 & 9.739 & 0.924 & 0.908 & 2.265 & 1.507 & 36.171 & 1.183 & 3.175 & 58.113 \\
\hline & SD & $(18.160)$ & (3.992) & (11.677) & (6.349) & (3.624) & (2.474) & (4.768) & (3.566) & $(20.176)$ & (3.461) & (3.220) & (15.494) \\
\hline \multirow[t]{2}{*}{ OLS } & Coeff. & $-16.318^{\star \star \star}$ & $-1.975^{\star \star \star}$ & $2.761^{\star \star \star}$ & $1.124^{\star \star \star}$ & 0.011 & $0.225^{\star \star}$ & $0.903^{\star \star \star}$ & $0.361^{*}$ & $6.603^{\star \star \star}$ & -0.160 & $0.430^{\star *}$ & $3.272^{\star \star \star}$ \\
\hline & $\mathrm{SE}$ & $(0.689)$ & $(0.136)$ & $(0.618)$ & $(0.400)$ & $(0.071)$ & $(0.099)$ & $(0.271)$ & $(0.192)$ & $(1.164)$ & $(0.164)$ & $(0.217)$ & $(0.836)$ \\
\hline \multirow[t]{2}{*}{$\mathrm{RD}$} & Coeff. & $-27.645^{\star \star \star}$ & $-3.342^{\star \star \star}$ & $6.598^{\star \star \star}$ & $3.195^{\star \star}$ & $0.592^{*}$ & 0.265 & $2.479^{\star \star \star}$ & $1.542^{\star \star \star}$ & $13.759^{\star \star \star}$ & 0.298 & -0.541 & 1.578 \\
\hline & SE & $(1.584)$ & $(0.364)$ & $(1.847)$ & $(1.241)$ & $(0.339)$ & $(0.289)$ & $(0.764)$ & $(0.543)$ & $(3.472)$ & $(0.537)$ & $(0.653)$ & $(2.552)$ \\
\hline \multirow[t]{2}{*}{ FE } & $\begin{array}{l}\text { Coeff. } \\
\text { SE }\end{array}$ & $\begin{array}{c}-19.726^{\star \star \star} \\
(0.895)\end{array}$ & $\begin{array}{l}-2.393^{\star \star \star} \\
(0.205)\end{array}$ & $\begin{array}{l}5.642^{\star \star \star} \\
(1.084)\end{array}$ & $\begin{array}{l}2.007^{\star \star} \\
(0.982)\end{array}$ & $\begin{array}{c}0.077 \\
(0.105)\end{array}$ & $\begin{array}{c}0.010 \\
(0.137)\end{array}$ & $\begin{array}{l}0.754^{\star \star} \\
(0.360)\end{array}$ & $\begin{array}{l}0.557^{\star \star} \\
(0.256)\end{array}$ & $\begin{array}{l}7.341^{\star \star \star} \\
(1.812)\end{array}$ & $\begin{array}{r}-0.534^{\star} \\
(0.285)\end{array}$ & $\begin{array}{l}1.264^{\star \star \star} \\
(0.444)\end{array}$ & $\begin{array}{r}2.794^{*} \\
(1.639)\end{array}$ \\
\hline & $N$ & 5,769 & 5,787 & 3,676 & 2,772 & 5,809 & 5,773 & 5,701 & 5,711 & 3,651 & 3,684 & 2,759 & 3,663 \\
\hline
\end{tabular}

${ }^{*}$ Significant at the $10 \%$ level, ${ }^{* \star}$ at the $5 \%$ level, and ${ }^{\star \star \star}$ at the $1 \%$ level. Amounts are expressed in 2015 euros. Control variables are included. 


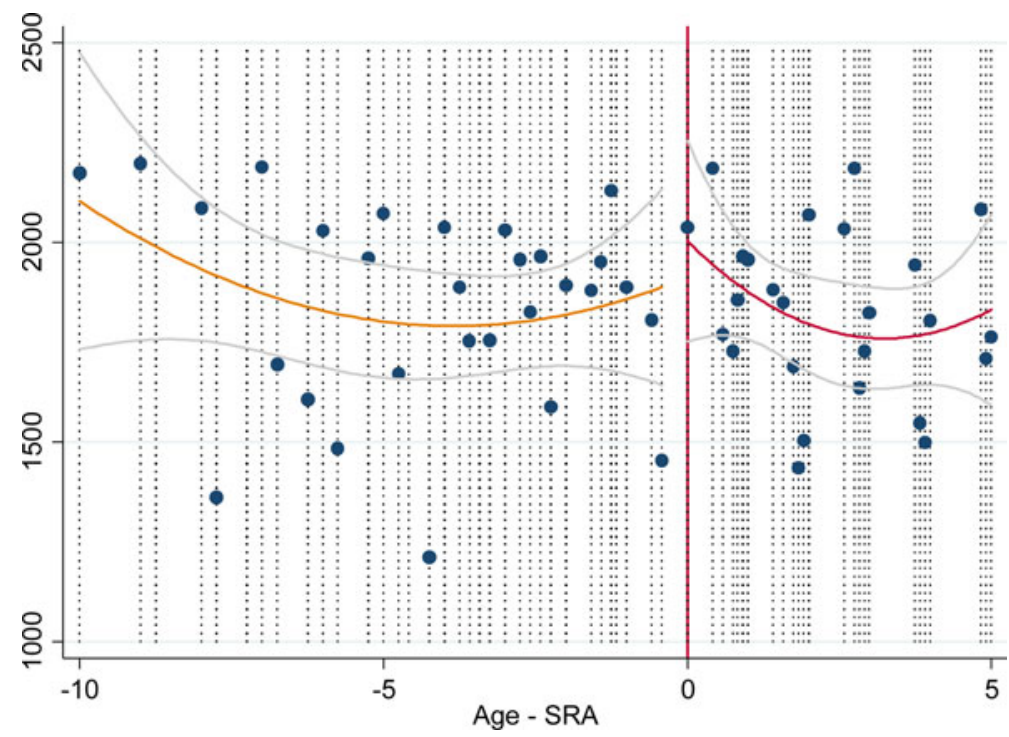

Figure 2. Average total household consumption spending (euros per month) by age. Notes: Lower- and upper bounds of the $95 \%$ interval are presented in light gray lines.

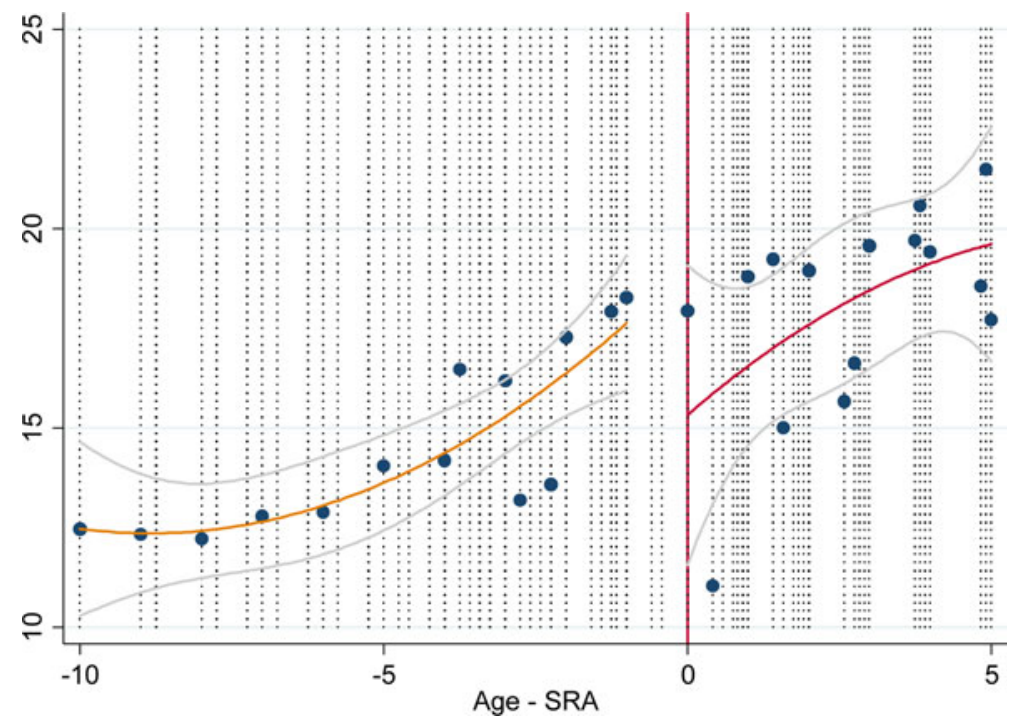

Figure 3. Average home production (hours per week) by age. Notes: Lower- and upper bounds of the $95 \%$ interval are presented in light gray lines.

time (in hours per week) increases significantly upon reaching the SRA (the upper bound of the confidence interval before reaching the SRA is below the lower bound of the confidence interval upon reaching the SRA). However, these results should be interpreted with caution as no causal claims can be made on the basis of these figures. In Section 3, we provide a comprehensive empirical approach that allows us to make causal claims.

In Appendix B, we visually show that background characteristics do not jump upon reaching the SRA. Additionally, we show the McCrary test (McCrary, 2008) in Figure B7. We do not find a discrete 


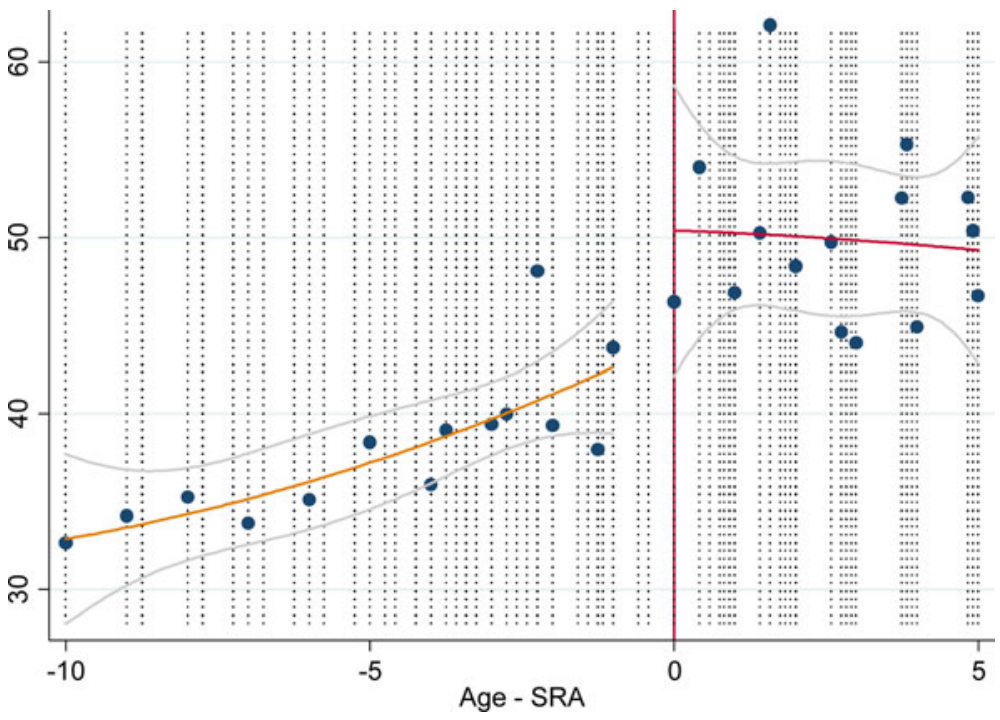

Figure 4. Average leisure time (hours per week) by age. Notes: Lower- and upper bounds of the $95 \%$ interval are presented in light gray lines.

jump in responses to spending questions at the SRA. If anything, the figure suggests a jump in responses about 2 years before the SRA. The figure suggests that retirees are more likely to participate in the survey. Since our data are a panel and not a cross-section, this may pose less of a threat to the identification of the RD than suggested by McCrary (2008) as most respondents are observed before and after reaching the SRA. Since FE estimation is possible with panel data and is less vulnerable to this issue, it is an important empirical approach to corroborate our findings.

\section{Empirical model}

To infer a causal relationship between retirement and consumption spending and time use categories, we use a fuzzy RD design, with a jump in the probability of retirement at the SRA that is greater than zero but less than one. We estimate:

$$
\begin{gathered}
y_{i t}=\alpha_{1}+\beta_{1} \cdot \text { Retired }_{i t}+\delta_{1} f\left(A_{i t}\right)+X_{i t}^{\prime} \theta_{1}+\epsilon_{i t} \\
\text { Retired }_{i t}=\alpha_{2}+\beta_{2} D_{i t}+\delta_{2} f\left(A_{i t}\right)+\vartheta_{2} D_{i t} \cdot f\left(A_{i t}\right)+X_{i t}^{\prime} \gamma_{2}+\mu_{i t}
\end{gathered}
$$

with

$$
\begin{gathered}
D_{i t}=1\left(\operatorname{age}_{i t} \geq S R A_{i t}\right), \\
A_{i t}=\left(a g e_{i t}-S R A_{i t}\right),
\end{gathered}
$$

and

$$
65 \leq S R A_{i t} \leq 67.25
$$

Here, SRA is based on the cohort-dependent statutory retirement age. Prior to 2013, $S R A=65$ for every cohort. From 2013, $S R A=65+d$ with $d=\{1 / 12, \ldots, 2.25\}$ where $d$ depends on the birth cohort. 
The exact birth date-dependent SRA can be observed in Table 1. In Equation (1), $y$ measures either consumption spending or time use in levels. Retired indicates whether a respondent's most important occupation is being retired (one if retired and zero otherwise), $f(\cdot)$ denotes some smooth function of the running variable $A$ (i.e., age minus SRA), and $X_{i}{ }_{i}$ is a vector of control variables ${ }^{18}$ : gender, having a partner, number of kids in the household, being an immigrant, low education dummy, high education dummy, and period effects. $D$ is the discontinuity introduced by the SRA which affects retirement, but has no direct effect on spending and time use behavior other than through the retirement decision. Like in the second-stage equation, $f(\cdot)$ denotes some smooth function of the running variable $A$ in the first stage (Equation 2). The term $D_{i t} \cdot f\left(A_{i t}\right)$ allows the slope to be flexible on each side of the threshold consistent with Figure 1 . Our baseline estimate assumes that $f(\cdot)$ is quadratic following the visual evidence in Figure 1. In Appendix Table D1, we show the estimation results for assuming a linear or cubic function of $f(\cdot)$ and show that estimation results are robust to the functional form of age. Results are also robust to the exclusion of $X^{\prime}{ }_{i}$ as well as conditioning on time-invariant unobserved heterogeneity (Table D1).

The error terms $\epsilon$ and $\mu$ are assumed to be correlated. Error distributions and the joint error distribution are assumed to be iid and normal. We estimate Equations (1) and (2) simultaneously through Maximum Likelihood using a 2SLS routine. The 'instrument', based on the discontinuity at the SRA, is likely to affect the choice of retirement (e.g., relevance), ${ }^{19}$ but is not likely to affect consumption decisions other than through the retirement decision (e.g., validity). Our approach is, therefore, similar to an IV approach in which the discontinuity at the SRA is an instrument for retirement.

Although an $\mathrm{RD}$ is very attractive, because of its simple nature, the approach has clear limitations which should be noted. At best, an RD estimates Local Average Treatment Effects (LATE) at the threshold. Only with very specific assumptions, e.g., constant treatment effects, the RD estimates an average treatment effect. Next, since the RD is fuzzy, there are both compliers $\left(\right.$ Retired $_{i t}=1 \mid D_{i t}=$ 1) and non-compliers to the 'treatment' $\left(\right.$ Retired $_{i t}=1 \mid D_{i t}=0$ and Retired $\left._{i t}=0 \mid D_{i t}=1\right)$. Hence, $\beta_{2}$ estimates a LATE for compliers at the threshold. This limits the external validity of the RD results for the population.

Luengo-Prado and Sevilla (2012) and Bonsang and Van Soest (2020) propose that it is sufficient to condition on unobserved time-invariant heterogeneity $v_{i}$ to infer causal effects of retirement on consumption. Correcting for household-specific unobserved effects should make the error-term independent of retirement in the spending and time use equations. We apply a FE model to check the sensitivity of our $\mathrm{RD}$ results:

$$
y_{i t}=\alpha_{1}+\beta_{1} \cdot \text { Retired }_{i t}+\delta_{1} f\left(A_{i t}\right)+X_{i t}^{\prime} \gamma_{1}+v_{i}+\epsilon_{i t} .
$$

\section{Estimation results}

\subsection{Total spending and household spending categories}

The estimated effects of retirement on household-level consumption categories are presented in Table 3. We present the results for naïve OLS estimation, RD (like Stancanelli and Van Soest, 2012), and FE (like Luengo-Prado and Sevilla, 2012).

Regardless of the estimation method, we do not find a significant drop in households' total consumption spending (the sum of household-level categories and personal-level categories summed to

\footnotetext{
${ }^{18}$ In the full estimation results in Table C2 we show that these characteristics significantly explain consumption spending with the a priori expected sign. This suggests that our data have reasonable variation to detect meaningful differences between households.

${ }^{19}$ In Appendix Table C2, we present full estimation results of the first stage of the RD. The table includes information on the F-statistics of the excluded instruments, i.e., the discontinuity. These F-statistics suggest that the RD is a strong instrument in the IV.
} 
the household level). In the FE-specification, we even find a very small but just-significant increase in total spending. Changing definitions of total spending, for example, by excluding spending on mortgage payments, rent, interest on debt, alimony, and general utilities (these spending categories are relative inflexibility to adjust), does not alter the main conclusions. Considering a total spending category excluding these categories shows that retirement increases total spending (non-significantly) by 170 euros which is close to the 163 euros from our baseline estimates.

In our preferred RD-specification, we find significant increases in spending on food at home (about $61(19 \%)$ euros per month) and spending on vacations/trips (43 (36\%) euros per month) only. These results are corroborated by the FE-specification though estimated effects tend to be smaller in the FE-specification. The increase in food at home spending might suggest increases in home production at retirement. We investigate this further by analyzing spending on food outside of the home in Section 4.2 and time spent on home production in Section 4.3. We find little to no evidence for spending categories that decrease at retirement. Although spending on transport is likely to decrease at retirement, our definition of transport costs does not explicitly exclude leisure-related use of transport. Therefore, the lack of decreases found in transport costs might be explained by leisure-complementary spending. Similarly, the increased spending on vacations/trips may represent leisure-complementary spending. However, we should remain careful in interpreting the coefficients of the spending categories as true null-effects, because standard errors are substantive in many categories.

For the full estimation results of the most important household-level spending categories, we refer to Tables $\mathrm{C} 1$ and $\mathrm{C} 2$.

\subsection{Personal spending categories at the household level}

The estimated effects of retirement on personal-level consumption categories are presented in Table 4. Similar to the total of consumption spending and the total of household-level spending (Table 3), we find no drop in total personal-level spending at retirement. Neither do we find substantial changes in personal-level spending patterns at retirement in our preferred RD-specification.

Interestingly, we find no significant decreases in spending on food outside of the home at retirement although this type of spending can be replaced by home production in the form of home cooking. We find increases in home cooking (see Table 3), but this apparently does not replace food outside of the home, contrasting the findings by Aguiar and Hurst (2005) for US households. Explicitly estimating the effect of retirement on food out relative to food in shows a decrease, but this decrease is not significant and suggests an absence of substitution between food outside the home and food at home spending. ${ }^{20}$ We further analyze home production at retirement using time use information in Section 4.3.

Unlike household-level leisure spending (e.g., vacations/trips), we find no significant increases in personal-level leisure spending. This may suggest leisure-time complementarities between spouses at retirement consistent with Stancanelli and Van Soest (2012). This is further corroborated by the heterogeneity analysis we present in Table 6 in which we show that leisure time is primarily increased among couples. By focusing on leisure-complementary spending and adding the spending categories of vacations, food out, and personal leisure spending to one category shows that retirement significantly increases total leisure-complementary spending by about 104 euros per month. ${ }^{21}$ Therefore, most of the (non-significant) increase in total spending (163 euros) we find is due to increased spending on leisure-complementary goods and services.

We find no drops in personal work-related expenditures, such as clothing. This is consistent with the absence of finding significant decreases in transport costs. However, our level of detail is too aggregated to identify whether clothing spending is related to work or leisure. Therefore, not finding a change in clothing might also suggest complementarities between this category and leisure up to

\footnotetext{
${ }^{20}$ The effect of retirement on ( food out/food in $) \times 100$ is $-3.343(\mathrm{SE}=10.932, N=2,454)$.

${ }^{21}$ This is 144 euros per month if we also add the categories other (hh) and other (personal) which are likely to include leisure-related spending.
} 
Table 6. Heterogeneous effects of retirement on spending and time use

\begin{tabular}{|c|c|c|c|c|c|c|c|c|c|c|c|c|c|}
\hline & & & \multicolumn{7}{|c|}{ Spending } & \multicolumn{4}{|c|}{ Time use } \\
\hline & & & Transport & Cleaning & Food in & Vacation & Food out & Leisure & Total & Work & Commute & Home & Leisure \\
\hline \multirow[t]{2}{*}{ Men } & $\mathrm{RD}$ & $\begin{array}{l}\text { Coeff. } \\
\text { SE }\end{array}$ & $\begin{array}{c}17.189 \\
(17.594)\end{array}$ & $\begin{array}{c}9.124 \\
(8.345)\end{array}$ & $\begin{array}{l}77.490^{\star *} \\
(31.482)\end{array}$ & $\begin{array}{l}79.774^{\star \star *} \\
(27.013)\end{array}$ & $\begin{array}{c}20.564 \\
(15.429)\end{array}$ & $\begin{array}{c}18.515 \\
(17.279)\end{array}$ & $\begin{array}{c}235.016 \\
(158.926)\end{array}$ & $\begin{array}{c}-29.331^{* * *} \\
(1.758)\end{array}$ & $\begin{array}{l}-3.921^{\star \star \star} \\
(0.444)\end{array}$ & $\begin{array}{l}6.121^{\star \star \star} \\
(1.860)\end{array}$ & $\begin{array}{l}10.603^{\star \star \star} \\
(3.763)\end{array}$ \\
\hline & & $N$ & 3,791 & 3,791 & 3,791 & 3,791 & 1,873 & 1,873 & 3,791 & 3,736 & 3,761 & 2,448 & 2,431 \\
\hline \multirow[t]{3}{*}{ Women } & $\mathrm{RD}$ & Coeff. & -26.224 & 8.579 & 5.641 & -2.706 & -0.905 & -3.423 & 159.811 & $-18.670^{\star \star \star *}$ & $-1.349^{\star \star}$ & $7.543^{\star}$ & $14.962^{\star \star}$ \\
\hline & & SE & -20.734 & -14.834 & -45.939 & -29.807 & -24.165 & -24.972 & -219.006 & -2.400 & $(0.579)$ & -4.212 & -6.938 \\
\hline & & $N$ & 2,024 & 2,024 & 2,024 & 2,024 & 878 & 878 & 2,024 & 2,033 & 2,026 & 1,228 & 1,220 \\
\hline \multirow[t]{2}{*}{ Single } & $\mathrm{RD}$ & $\begin{array}{l}\text { Coeff. } \\
\text { SE }\end{array}$ & $\begin{array}{l}-7.302 \\
(20.522)\end{array}$ & $\begin{array}{c}3.644 \\
(12.557)\end{array}$ & $\begin{array}{c}30.765 \\
(37.168)\end{array}$ & $\begin{array}{c}4.581 \\
(14.962)\end{array}$ & $\begin{array}{c}37.188 \\
(24.796)\end{array}$ & $\begin{array}{r}-10.474 \\
(24.479)\end{array}$ & $\begin{array}{l}341.873^{*} \\
(178.620)\end{array}$ & $\begin{array}{c}-22.540^{\star \star \star *} \\
(2.491)\end{array}$ & $\begin{array}{l}-2.870^{\star \star \star} \\
(0.598)\end{array}$ & $\begin{array}{c}5.175 \\
(3.779)\end{array}$ & $\begin{array}{l}7.267 \\
(6.494)\end{array}$ \\
\hline & & $N$ & 2,034 & 2,034 & 2,034 & 2,034 & 879 & 879 & 2,034 & 2,043 & 2,042 & 1,201 & 1,202 \\
\hline \multirow[t]{2}{*}{ Couple } & $\mathrm{RD}$ & $\begin{array}{l}\text { Coeff. } \\
\text { SE }\end{array}$ & $\begin{array}{l}-1.385 \\
(18.039)\end{array}$ & $\begin{array}{c}2.815 \\
(8.742)\end{array}$ & $\begin{array}{l}69.541^{\text {** }} \\
(34.389)\end{array}$ & $\begin{array}{l}62.143^{\star *} \\
(30.925)\end{array}$ & $\begin{array}{c}11.599 \\
(15.205)\end{array}$ & $\begin{array}{c}23.806 \\
(17.030)\end{array}$ & $\begin{array}{r}25.869 \\
(170.269)\end{array}$ & $\begin{array}{c}-28.845^{\star \star *} \\
(1.870)\end{array}$ & $\begin{array}{l}-3.294^{\star * *} \\
(0.443)\end{array}$ & $\begin{array}{l}7.312^{\text {***}} \\
(2.033)\end{array}$ & $\begin{array}{l}16.171^{\text {***}} \\
(4.024)\end{array}$ \\
\hline & & $N$ & 3,781 & 3,781 & 3,781 & 3,781 & 1,872 & 1,872 & 3,781 & 3,726 & 3,745 & 2,475 & 2,449 \\
\hline \multirow[t]{2}{*}{ Dual-earner } & $\mathrm{RD}$ & $\begin{array}{l}\text { Coeff. } \\
\text { SE }\end{array}$ & $\begin{array}{c}6.093 \\
(38.602)\end{array}$ & $\begin{array}{c}10.778 \\
(15.511)\end{array}$ & $\begin{array}{c}72.176 \\
(66.213)\end{array}$ & $\begin{array}{r}121.428^{*} \\
(65.328)\end{array}$ & $\begin{array}{l}-5.350 \\
(38.341)\end{array}$ & $\begin{array}{r}-69.256 \\
(45.773)\end{array}$ & $\begin{array}{c}257.759 \\
(333.853)\end{array}$ & $\begin{array}{l}-25.111^{\star \star \star *} \\
(3.653)\end{array}$ & $\begin{array}{l}-2.451^{\star * \star} \\
(0.844)\end{array}$ & $\begin{array}{c}-2.702 \\
(5.142)\end{array}$ & $\begin{array}{l}14.362 \\
(9.532)\end{array}$ \\
\hline & & $N$ & 1,852 & 1,852 & 1,852 & 1,852 & 957 & 957 & 1,852 & 1,859 & 1,858 & 1,196 & 1,178 \\
\hline \multirow[t]{2}{*}{ Single-earner } & $\mathrm{RD}$ & $\begin{array}{c}\text { Coeff. } \\
\text { SE }\end{array}$ & $\begin{array}{c}-20.954 \\
(15.380)\end{array}$ & $\begin{array}{c}3.613 \\
(8.625)\end{array}$ & $\begin{array}{c}49.171^{*} \\
(29.617)\end{array}$ & $\begin{array}{c}26.607 \\
(22.844)\end{array}$ & $\begin{array}{c}7.382 \\
(15.546)\end{array}$ & $\begin{array}{l}35.689^{\star *} \\
(16.852)\end{array}$ & $\begin{array}{c}181.079 \\
(147.709)\end{array}$ & $\begin{array}{c}-27.240^{\star \star \star} \\
(1.776)\end{array}$ & $\begin{array}{c}-3.312^{\star * *} \\
(0.419)\end{array}$ & $\begin{array}{l}7.033^{\star * *} \\
(2.076)\end{array}$ & $\begin{array}{l}15.777^{\star \star * *} \\
(3.916)\end{array}$ \\
\hline & & $N$ & 3,963 & 3,963 & 3,963 & 3,963 & 1,794 & 1,794 & 3,963 & 3,910 & 3,929 & 2,480 & 2,473 \\
\hline \multirow[t]{2}{*}{ Low-edu } & $\mathrm{RD}$ & $\begin{array}{l}\text { Coeff. } \\
\text { SE }\end{array}$ & $\begin{array}{r}-28.295 \\
(20.911)\end{array}$ & $\begin{array}{l}-2.476 \\
(10.629)\end{array}$ & $\begin{array}{c}43.005 \\
(47.077)\end{array}$ & $\begin{array}{c}11.532 \\
(35.194)\end{array}$ & $\begin{array}{c}6.270 \\
(21.829)\end{array}$ & $\begin{array}{c}35.150 \\
(24.796)\end{array}$ & $\begin{array}{c}75.160 \\
(217.261)\end{array}$ & $\begin{array}{c}-22.798^{\star \star \star} \\
(2.928)\end{array}$ & $\begin{array}{l}-3.602^{\star \star \star} \\
(0.655)\end{array}$ & $\begin{array}{l}8.920^{\star \star \star} \\
(3.403)\end{array}$ & $\begin{array}{c}7.413 \\
(5.901)\end{array}$ \\
\hline & & $N$ & 1,850 & 1,850 & 1,850 & 1,850 & 1,014 & 1,014 & 1,850 & 1,837 & 1,839 & 1,262 & 1,250 \\
\hline \multirow[t]{2}{*}{ High-edu } & $\mathrm{RD}$ & $\begin{array}{l}\text { Coeff. } \\
\text { SE }\end{array}$ & $\begin{array}{c}6.989 \\
(26.218)\end{array}$ & $\begin{array}{c}20.961 \\
(13.736)\end{array}$ & $\begin{array}{r}9.610 \\
(43.469)\end{array}$ & $\begin{array}{l}83.593^{\star \star} \\
(38.439)\end{array}$ & $\begin{array}{r}40.712^{*} \\
(22.136)\end{array}$ & $\begin{array}{r}3.650 \\
(21.962)\end{array}$ & $\begin{array}{c}94.579 \\
(228.764)\end{array}$ & $\begin{array}{c}-26.704^{\star \star \star} \\
(2.346)\end{array}$ & $\begin{array}{l}-2.516^{\star \star \star} \\
(0.576)\end{array}$ & $\begin{array}{c}3.210 \\
(2.471)\end{array}$ & $\begin{array}{l}13.359^{\star *} \\
(5.190)\end{array}$ \\
\hline & & $N$ & 2,072 & 2,072 & 2,072 & 2,072 & 893 & 893 & 2,072 & 2,065 & 2,073 & 1,258 & 1,254 \\
\hline \multirow[t]{2}{*}{ Low-inc it-1 } & $\mathrm{RD}$ & $\begin{array}{l}\text { Coeff. } \\
\text { SE }\end{array}$ & $\begin{array}{c}28.057 \\
(36.978)\end{array}$ & $\begin{array}{c}0.597 \\
(17.033)\end{array}$ & $\begin{array}{l}204.179^{\star * *} \\
(73.834)\end{array}$ & $\begin{array}{c}52.220 \\
(53.781)\end{array}$ & $\begin{array}{c}-23.333 \\
(51.206)\end{array}$ & $\begin{array}{c}44.890 \\
(58.321)\end{array}$ & $\begin{array}{c}256.706 \\
(343.188)\end{array}$ & $\begin{array}{c}-9.564^{\star \star} \\
(3.849)\end{array}$ & $\begin{array}{c}-0.099 \\
(0.730)\end{array}$ & $\begin{array}{c}-0.740 \\
(6.140)\end{array}$ & $\begin{array}{c}4.086 \\
(9.884)\end{array}$ \\
\hline & & $N$ & 2,559 & 2,559 & 2,559 & 2,559 & 1,201 & 1,201 & 2,559 & 2,550 & 2,555 & 1,629 & 1,617 \\
\hline \multirow[t]{2}{*}{ High-inc it-1 } & $\mathrm{RD}$ & $\begin{array}{l}\text { Coeff. } \\
\text { SE }\end{array}$ & $\begin{array}{c}59.399 \\
(80.609)\end{array}$ & $\begin{array}{r}-24.910 \\
(37.274)\end{array}$ & $\begin{array}{c}51.680 \\
(145.826)\end{array}$ & $\begin{array}{c}178.228 \\
(119.405)\end{array}$ & $\begin{array}{c}45.271 \\
(69.794)\end{array}$ & $\begin{array}{c}89.156 \\
(59.542)\end{array}$ & $\begin{array}{r}-209.804 \\
(703.019)\end{array}$ & $\begin{array}{c}-37.332^{\star \star \star} \\
(10.508)\end{array}$ & $\begin{array}{r}-3.735^{\star} \\
(2.106)\end{array}$ & $\begin{array}{l}21.343^{\star *} \\
(10.755)\end{array}$ & $\begin{array}{c}29.951^{*} \\
(17.862)\end{array}$ \\
\hline & & $N$ & 807 & 807 & 807 & 807 & 326 & 326 & 807 & 790 & 799 & 501 & 500 \\
\hline \multirow[t]{2}{*}{ No debt } & $\mathrm{RD}$ & $\begin{array}{l}\text { Coeff. } \\
\text { SE }\end{array}$ & $\begin{array}{l}-4.761 \\
(15.332)\end{array}$ & $\begin{array}{c}2.191 \\
(7.939)\end{array}$ & $\begin{array}{l}66.436^{\star \star} \\
(29.032)\end{array}$ & $\begin{array}{l}49.890^{\star \star} \\
(23.889)\end{array}$ & $\begin{array}{c}10.354 \\
(14.495)\end{array}$ & $\begin{array}{c}13.144 \\
(15.781)\end{array}$ & $\begin{array}{c}182.432 \\
(143.003)\end{array}$ & $\begin{array}{c}-27.327^{\star \star \star} \\
(1.711)\end{array}$ & $\begin{array}{c}-3.331^{\star \star \star} \\
(0.393)\end{array}$ & $\begin{array}{l}6.541^{\star \star \star} \\
(2.003)\end{array}$ & $\begin{array}{l}12.343^{\star \star \star} \\
(3.723)\end{array}$ \\
\hline & & $N$ & 5,216 & 5,216 & 5,216 & 5,216 & 2,436 & 2,436 & 5,216 & 5,117 & 5,133 & 3,259 & 3,236 \\
\hline \multirow[t]{2}{*}{ No rent } & $\mathrm{RD}$ & $\begin{array}{l}\text { Coeff. } \\
\text { SE }\end{array}$ & $\begin{array}{r}-5.918 \\
-17.546\end{array}$ & $\begin{array}{r}6.683 \\
-9.131\end{array}$ & $\begin{array}{l}66.325^{\star \star} \\
-32.911\end{array}$ & $\begin{array}{l}65.497^{\star \star} \\
-27.500\end{array}$ & $\begin{array}{r}8.510 \\
-14.914\end{array}$ & $\begin{array}{r}9.141 \\
-16.542\end{array}$ & $\begin{array}{r}144.990 \\
-164.339\end{array}$ & $\begin{array}{l}-28.765^{\star \star \star} \\
-1.840\end{array}$ & $\begin{array}{l}-3.614^{\star \star \star} \\
(0.428)\end{array}$ & $\begin{array}{l}6.242^{\star \star \star} \\
-2.051\end{array}$ & $\begin{array}{l}15.263^{\star \star *} \\
-3.915\end{array}$ \\
\hline & & $N$ & 4,359 & 4,359 & 4,359 & 4,359 & 2,031 & 2,031 & 4,359 & 4,272 & 4,283 & 2,715 & 2,690 \\
\hline
\end{tabular}

*Significant at the $10 \%$ level, ** at the $5 \%$ level, and *** at the $1 \%$ level. Amounts are expressed in 2015 euros. Control variables are included. Low income is below the p 25 which is the bottom quartile of gross income of non-retirees aged 55-75: 1,500 euros per month. p75 is the top quartile of gross income of non-retirees aged 55-75: 3,500 euros per month. 
some extent. Again, we should remain careful in interpreting the coefficients of the spending categories as true null-effects, because standard errors are substantive in many categories.

For the full estimation results of the most important personal-level spending categories, we refer to Tables $\mathrm{C} 1$ and $\mathrm{C} 2$.

\subsection{Time use categories}

In Table 5, we present the estimated effects of retirement on time use categories. Compared to our estimates for spending categories, estimates for time use are much more precise. For our preferred $\mathrm{RD}$-specification, we find that paid working hours decrease by about 28 hours per week at retirement which is a decrease of about $100 \%$. Similarly, commuting time decreases by about 3 hours per week $(100 \%)$ at retirement. Many of the hours related to work and commuting are reallocated toward leisure, personal- and informal care, and home production. In our preferred RD-estimation, we find an increase in pure leisure time (excluding sleeping/resting) of about 14 hours per week (38\%). The increase in leisure at retirement is about $50 \%$ of the foregone work hours. Similarly, home production increases by about 6.5 hours per week (47\%) and absorbs about a quarter of all foregone working hours. This is consistent with using the intensive margin of labor supply instead of a retirement dummy (Table 2, work hours). These effects are corroborated by the FE-specification though estimated effects are smaller.

Despite the substantial increase in time spent on home production at retirement, we do not find decreases in replaceable spending categories (cleaning, food out) in Tables 3 and 4. This suggests that retirees do not replace spending categories, but increase home production without replacing spending categories. Increasing home production without replacing spending is likely due to having more nonwork time available at retirement. This is consistent with our estimation results regarding spending on home cooking and food outside of the home in Tables 3 and 4, respectively. These results show increases in food at home without any decreases in food out. To explain these results, it should be noted that food out has a strong leisure component in the Netherlands. Therefore, food at home and food out may not be perfect substitutes and the lack of decreases in food out spending is most likely explained by the fact that food out spending is leisure-complementary. Our results largely contrast the findings of Aguiar and Hurst (2005) for US retirees, because we find no clear substitution between spending and home production for Dutch retirees. The shift toward more leisure-complementary spending and the increases in home production suggest that well-being might even increase at retirement.

For the full estimation results of the most important categories, we refer to Tables C1 and C2.

\subsection{Sensitivity}

In Table 2, we analyze the robustness of our results to different retirement definitions. This sensitivity analysis shows that the main effects found in the preferred baseline RD-estimation in Tables 3-5 are also found for the sample of reported time use in home production, full retirees, and (full-time) paid workers prior to retirement. Using an intensive labor supply measure instead of an extensive labor supply measure in the form of paid working hours does not change our main conclusions either.

To show the robustness of the $\mathrm{RD}$-specification we also use 'donut RD' (i.e., Barreca et al., 2011) where we do not take into account the observations within one year of the SRA. Also, we reduce the age-window to respondents aged 60-70 to investigate the robustness of the RD results. A final check is to use 65 as a fixed SRA and only using the period prior to 2013 in which the SRA was 65 for all cohorts. All approaches give results similar to our baseline RD in Tables 3-5. Using age measured in months instead of years reduces the number of observations substantially by mostly leaving out pre-2013 respondents. This may drive the slightly changing coefficients and significance, although using age measured in months does not alter the main conclusions of the paper.

In Appendix D Table D2, we also present the estimation results if we use lags of responses in spending and time use, log-transformed dependent variables, and IV-Tobit estimation. These estimates do not change our main conclusions. However, considering spending and time use categories 
at time $t+1$ to account for a potential lack of immediate effects of retirement suggests that changes in spending behavior at retirement may take a longer adjustment period.

In Appendix E, we shed more light on the smoothing of consumption at retirement by analyzing respondents' subjective expectations regarding consumption and income as well as objective measures of gross and net income. The empirical evidence in Table E1 suggests that gross monthly income does not change at retirement whereas net monthly income increases by about $8 \%$. Respondents do not expect a decrease in income and consumption opportunities at retirement, but they are positively surprised by their financial situation at retirement. These additional results are consistent with the simulated net replacement rates of about $100 \%$ for at least half of the Dutch households (Knoef et al., 2016) and corroborate our lack of drops in total spending at retirement.

\subsection{Heterogeneity}

In Table 6, we present the estimation results for a range of subsamples in order to identify the extent to which our main results are representative of different groups of households. The effects of retirement on spending are remarkably homogeneous among the defined subsamples, even for potentially vulnerable groups such as women, singles, low-educated, immigrants, and liquidity-constrained (i.e., renting/ those with debt). This is consistent with Knoef et al. (2016), who show that vulnerable groups have median replacement rates that are relatively close to the population's average. Nonetheless, there is, of course, substantial heterogeneity in the level of spending between aforementioned groups. The results for the subgroups should, however, be interpreted with caution because, spending categories are often estimated relatively imprecisely due to the large variation in responses.

For time use, which is estimated more precisely than spending, we find more heterogeneity among the subgroups. We especially find substantial differences in home production and leisure between gender, couples/singles, and high/low income. Interestingly, respondents who are a couple report bigger increases in leisure time and spending on vacations which corroborate our earlier suggestion that joint leisure may be important in spending and time use decisions. Our main conclusions regarding the lack of total spending drops, the lack of substitution between spending and home production, and complementariness in leisure-related spending are largely confirmed for these subsamples of households.

Knoef et al. (2016) and Been and Knoef (2017) also indicate that the self-employed are potentially vulnerable due to a potential lack of occupational pension accumulation and a bad labor market position at older ages. Unfortunately, our number of self-employed is too small to do estimates on this subsample. However, by performing estimates with an interaction between retirement and selfemployment at time $t-1$, we observe very little heterogeneity between paid employed and selfemployed. This suggests that, on average, self-employed are also able to smooth consumption without substituting toward home production.

\section{Quantitative implications for the Life-Cycle Model}

Our empirical results suggest that (1) Dutch households do not face a drop in spending at retirement and (2) Dutch households do not replace spending by home production at retirement. ${ }^{22}$ These results are at odds with the empirical evidence from US households. This cross-country difference suggests that intratemporal smoothing is likely to be larger if intertemporal smoothing is smaller and vice versa. Rogerson and Wallenius (2016) are the first to theoretically show how the intertemporal elasticity of substitution of leisure and the intratemporal elasticity of substitution between spending and time interact in a simple LCM. The authors show how information on spending and time use can be combined to approximate the size of these elasticities.

\footnotetext{
${ }^{22}$ This is consistent with empirical evidence from other European countries, such as France (Moreau and Stancanelli, 2015), Italy (Battistin et al., 2009), and Spain (Luengo-Prado and Sevilla, 2012), where the drop in consumption and the substitution between spending and home production is small or even absent.
} 


\subsection{The Life-Cycle Model of Rogerson and Wallenius (2016)}

The LCM of Rogerson and Wallenius (2016) makes two important assumptions regarding the parameterization of the model and the retirement decision. First, they assume that agents maximize the following CES utility function with the usual properties over the life-cycle

$$
U=\sum_{t=0}^{T}(1+\delta)^{-t}\left[u\left(c_{t}\right)+\theta \frac{l_{t}^{1-(1 / \gamma)}}{1-(1 / \gamma)}\right]
$$

with

$$
c_{t}=\left[a c_{m t}^{(\eta-1) / \eta}+(1-a) h_{n t}^{(\eta-1) / \eta}\right]^{\eta /(\eta-1)}
$$

subject to the intertemporal budget constraint

$$
\sum_{t=0}^{T} \frac{c_{m t}}{(1+\rho)^{t}}=\sum_{t=0}^{T} \frac{y_{t}}{(1+\rho)^{t}}
$$

and time budget constraint

$$
l_{t}=T-h_{m t}-h_{n t} .
$$

Here, $c_{t}$ is consumption in period $t=0, \ldots, T, l_{t}$ is hours of leisure, $\delta \geq 0$ the rate of time preference, $0 \leq \theta \leq 1$ the weight the agent gives to leisure, $c_{m t}$ is consumption spending, $h_{n t}$ time spent on home production, $a$ the relative weights given to spending and home production, $\rho=\delta$ is the interest rate assumed to be equal to the time preference, $h_{m t}$ time spent on market work, $T$ is the total time endowment in period $t$ normalized to one, and $y_{t}$ the income received in period $t$ which depends on $h_{m t}$ and a fixed wage $b$.

The parameters that Rogerson and Wallenius (2016) are primarily interested in are $\gamma$ and $\eta \cdot \gamma$ is the intertemporal elasticity of substitution for leisure and determines the curvature of the utility function. $\gamma=0$ yields full intertemporal smoothing. Higher values of $\gamma$ imply less smoothing. $\eta$ is the intratemporal elasticity of substitution between $c_{m t}$ and $h_{n t}$ and determines the extent to which expenditures are replaced by home production. $\eta=1$ yields no intratemporal smoothing by home production. $\eta \rightarrow \infty$ yields full intratemporal smoothing. In the case that $0<\eta<1$, home production and spending are complements instead of substitutes.

Second, the LCM of Rogerson and Wallenius (2016) assumes that the retirement decision is certain and abrupt. Hence, there is no room for uncertainty in the retirement decision or gradual retirement. Therefore, it is assumed that the employed work is a fixed number of hours $h_{m t}=h^{F}$. Only interior solutions for $l_{t}$ and $h_{n t}$ are considered.

Agents choose $c_{m t}$ and $h_{n t}$ to maximize Equation (7) subject to Equations (9) and (10). Rogerson and Wallenius (2016) show that substituting Equation (10) in Equation (7), calculating the Lagrangian, dividing the two first-order conditions for intertemporal substitution and intratemporal substitution, taking logs, and considering $t=\{w, r\}$ with $w$ employed and $r$ retired gives the following expression for the ratio of $\gamma$ and $\eta:^{23}$

$$
\frac{\gamma}{\eta}=\frac{\log \left(\left(1-h_{r}^{n}\right) /\left(1-h^{F}-h_{w}^{n}\right)\right)}{\log \left(c_{w}^{m} / c_{r}^{m}\right)-\log \left(h_{w}^{n} / h_{r}^{n}\right)} .
$$

\footnotetext{
${ }^{23}$ For details regarding the derivation of the result, we refer to page 25 in Rogerson and Wallenius (2016).
} 
This equation provides an expression for the ratio between the intertemporal elasticity of substitution for leisure, $\gamma$, and the intratemporal elasticity of substitution between spending and home production, $\eta$. More specifically, Equation (11) shows that the ratio between $\gamma$ and $\eta$ equals the relative change in leisure time divided by the difference between the relative change in consumption expenditure and the relative change in time spent on home production. By using empirical observations of US households from Hurd and Rohwedder (2005, 2007), Rogerson and Wallenius (2016) estimate a ratio of 0.92. An important conclusion from this ratio is that commonly assumed values in the literature for $\gamma(0.4)$ and $\eta(2.0)$ are inconsistent with this ratio. One of the explanations mentioned by Rogerson and Wallenius (2016) is that $\eta$ might be much smaller than generally assumed for US households, which is consistent with recent evidence from Been et al. (2021) who show that only parts of total spending are replaced by home production among US households at retirement.

\subsection{Implied parameters of the Life-Cycle Model}

According to our preferred $\mathrm{RD}$ model in Table 5, retirement increases time spent on leisure and home production by about $38 \%$ and $47 \%$, respectively. Table 3 indicates that total consumption spending does not change at retirement. These results give

$$
\begin{gathered}
\log \left(\left(1-h_{r}^{n}\right) /\left(1-h^{F}-h_{w}^{n}\right)\right)=\log (1.38) \\
\log \left(c_{w}^{m} / c_{r}^{m}\right)=\log (1.00) \\
\log \left(h_{w}^{n} / h_{r}^{n}\right)=\log (0.68) .
\end{gathered}
$$

Inserting these results in Equation (11) gives

$$
\gamma / \eta=0.82
$$

which is close to the estimates of Rogerson and Wallenius (2016) of $\gamma / \eta=0.92$ for US households. ${ }^{24}$ Contrasting our causal estimates of the effect of retirement on spending, home production and leisure, we should note that the empirical observations in Rogerson and Wallenius (2016) are based on summary statistics from cross-sectional time use data from Hurd and Rohwedder (2007) which cannot be interpreted causally.

Although the ratio is very similar for Dutch and US households, Dutch households do not face spending drops at retirement on average. Based on this cross-country comparison, we conclude that the intertemporal elasticity of substitution for leisure is most likely larger among Dutch households. More so, because we find no empirical evidence for intratemporal substitution between spending and home production. This suggests that $\eta$ may be close to one and, hence, smaller than $\eta$ estimated for US households (Aguiar and Hurst, 2007). This has two important implications. First, $\gamma$ is most likely below unity for Dutch households. This finding is consistent with stated preference evidence of the Netherlands from Kapteyn and Teppa (2003), although our revealed preferences estimate is closer to one, i.e., less intertemporal smoothing than suggested by Kapteyn and Teppa (2003). Second, next to $\eta, \gamma$ also is likely to be larger in the US if the ratio holds. Based on these results, it can be argued that intertemporal smoothing is relatively more important in smoothing consumption in the Netherlands than in the US.

\footnotetext{
${ }^{24}$ Based on our FE-specification, we estimate $\gamma / \eta=0.62$ which indicates a somewhat smaller ratio between the two elasticities. However, the main conclusions are robust to using either the RD estimates or the FE estimates.
} 


\section{Conclusion}

We provide new empirical evidence on the effect of retirement on spending and time use among Dutch households. The availability of a wide array of spending and time categories in our panel data allows us to study the effects of retirement on both total spending as well as on disaggregated categories of spending. These disaggregated categories give new insights into the interaction between spending and time use at retirement, such as increases in leisure-complementary spending (i.e., trips/ vacations) and decreases in goods that are replaceable by home production (i.e., eating out).

Using causal estimates from a fuzzy RD, like Stancanelli and Van Soest (2012) and corroborated by FE estimation, like Luengo-Prado and Sevilla (2012), we find no significant drops in total spending at retirement among Dutch households. This finding is consistent with estimates from other countries with relatively high pension replacement rates, such as France, Italy, and Spain, but contrasts the substantial drops in spending at retirement found among US households. In line with prior empirical evidence, we find substantial increases in time spent on home production and leisure activities at retirement (about 47\% and 38\%, respectively). However, we find no evidence for households substituting spending (eating out, cleaning) by home production at retirement. This suggests that much of the increase in home production at retirement is a consequence of having more non-work time available. Although we do not find significant changes in total spending at retirement, our analysis suggests that the composition of total spending changes at retirement. In particular, we find clear increases in spending that is complementary to leisure time (trips/vacations).

Inserting our estimates in the simple LCM of Rogerson and Wallenius (2016), we find that the ratio of the intertemporal elasticity of substitution for leisure and the intratemporal elasticity of substitution between time and goods in home production is about 0.82 . This result confirms that the ratio is close to one, like argued by Rogerson and Wallenius (2016). The lack of substitution between spending and home production we find for Dutch households, i.e., an intratemporal elasticity of substitution between spending and home production close to 1, suggests an elasticity of intratemporal substitution of leisure close to 0.82. Although the ratio is of similar size for Dutch and US households, the differences in actual spending drops at retirement suggest that both the intertemporal elasticity of substitution for leisure and the intratemporal elasticity of substitution between time and goods in home production are larger in the US than in the Netherlands. Intertemporal substitution is, therefore, more important in smoothing consumption than intratemporal substitution at retirement in the Netherlands and also relatively more important than in the US. Most likely, this can be explained by the high mandatory pension savings institutionalized in the Dutch pension system.

Supplementary material. The supplementary material for this article can be found at https://doi.org/10.1017/ S1474747221000330.

Financial support. Financial support from Instituut Gak is gratefully acknowledged. We thank Adriaan Kalwij, Marike Knoef, Pierre Koning, Mauro Mastrogiacomo, Arthur van Soest, Eduard Suari-Andreu, and Johanna Wallenius for comments on an earlier version of the paper and Eduard Suari-Andreu and Arthur van Soest for valuable discussions regarding the structure of the LISS consumption data. Marcel Das and Hans-Martin von Gaudecker are thanked for their cooperation in constructing the 2019 wave of the LISS Time Use and Consumption data. Finally, we thank the editors Eric French and Sita Slavov as well as two anonymous referees for helping improve the paper.

\section{References}

Aguiar M and Hurst E (2005) Consumption versus expenditure. Journal of Political Economy 113, 919-948. Aguiar M and Hurst E (2007) Life cycle prices and consumption. American Economic Review 97, 1533-1559.

Aguiar M and Hurst E (2009) Deconstructing lifecycle expenditure. (NBER Working Paper, No. 13893).

Aguila E, Attanasio O and Meghir C (2011) Changes in consumption at retirement: evidence from panel data. Review of Economics and Statistics 3, 1094-1099.

Ando A and Modigliani F (1963) The 'life cycle' hypothesis of saving: aggregate implications and tests. American Economic Review 53(1), 55-84.

Atav T, Jongen E and Rabaté S (2019) The effects of the increase in the retirement age in the Netherlands. (CPB Discussion Paper December 2019). 
Banks J, Blundell R and Tanner S (1998) Is there a retirement-savings puzzle? American Economic Review 88, 769-788.

Barreca AI, Guldi M, Lindo JM and Waddell GR (2011) Saving babies? Revisiting the effect of very low birth weight classification. Quarterly Journal of Economics 126, 2117-2123.

Battistin E, Brugiavini A, Rettore E and Weber G (2009) The retirement consumption puzzle: evidence from a regression discontinuity approach. American Economic Review 99, 2209-2226.

Becker G (1965) A theory of the allocation of time. The Economic Journal 75, 493-517.

Been J and Knoef M (2017) Job-search requirements for unemployed at the end of working life: effects on unemployment dynamics and self-employment probabilities. The Journal of Human Resources 52, 491-530.

Been J, Rohwedder S and Hurd M (2020) Does home production replace consumption spending? Evidence from shocks in housing wealth in the Great Recession. Review of Economics and Statistics 102, 113-128.

Been J, Rohwedder S and Hurd M (2021) Households' joint consumption spending and home production responses to retirement in the US. Review of Economics of the Household, forthcoming: doi:10.1007/s11150-020-09528-5.

Behaghel L and Blau D (2012) Framing social security reform: behavioral responses to changes in the Full Retirement Age. American Economic Journal: Economic Policy 4, 41-67.

Bernheim B, Skinner J and Weinberg S (2001) What accounts for the variation in retirement wealth among US households? American Economic Review 91, 832-857.

Blau DM (2008) Retirement and consumption in a life cycle model. Journal of Labor Economics 26, 35-71.

Boerma J and Karabarbounis L (2019) Inferring Inequality with Home Production. (NBER Working Paper, No. 24166).

Bonsang E and Van Soest A (2020) Time devoted to home production and retirement in couples: a panel data analysis. Labour Economics 65, 101-110.

Cherchye L, De Rock B and Vermeulen F (2012) Married with children: a collective labor supply model with detailed time use and intrahousehold expenditure information. American Economic Review 102(7), 3377-3405.

Cherchye L, Demuynck T, De Rock B and Vermeulen F (2017) Household consumption when the marriage is stable. American Economic Review 107(6), 1507-1534.

Ciani E (2016) Retirement, pension eligibility and home production. Labour Economics 38, 106-120.

De Grip A, Fouarge D and Montizaan R (2013) How sensitive are individual retirement expectations to raising the retirement age? De Economist 161, 225-251.

Duggan M, Singleton P and Song J (2007) Aching to retire? The rise in the Full Retirement Age and its impact on Social Security Disability rolls. Journal of Public Economics 91, 1327-1350.

Fisher JD, Johnson DS, Marchand J, Smeeding TM and Boyle Torrey B (2008) The retirement consumption conundrum: evidence from a consumption survey. Economics Letters 99, 482-485.

Haider S and Stephens M (2007) Is there a retirement-consumption puzzle? Evidence using subjective retirement expectations. Review of Economics and Statistics 89, 247-264.

Hurd M and Rohwedder S (2005) Changes in consumption and activities in retirement. (Michigan Retirement Research Center Working Paper 2005-096).

Hurd M and Rohwedder S (2006) Some answers to the retirement-consumption puzzle. (NBER Working Paper, No. 12057).

Hurd M and Rohwedder S (2007) Time-use in the older population. Variation by socio-economic status and health. (RAND Working Paper WR-463).

Hurst E (2008) The retirement of a consumption puzzle. (NBER Working Paper Series, No. 13789).

Kapteyn A and Teppa F (2003) Hypothetical Intertemporal Consumption Choices. The Economic Journal 113(486), 140152.

Kerkhofs M and Kooreman P (2003) Identification and estimation of a class of household production models. Journal of Applied Econometrics 18, 337-369.

Knoef M, Been J, Alessie R, Caminada K, Goudswaard K and Kalwij A (2016) Measuring retirement savings adequacy; developing a multi-pillar approach in the Netherlands. Journal of Pension Economics and Finance 15, 55-89.

Laitner J and Silverman D (2005) Estimating life-cycle parameters from consumption behavior at retirement. (NBER Working Paper Series, No. 11163).

Laitner J and Silverman D (2012) Consumption, retirement and social security: evaluating the efficiency of reform that encourages longer careers. Journal of Public Economics 96, 615-634.

Luengo-Prado MJ and Sevilla A (2012) Time to cook: expenditure at retirement in Spain. The Economic Journal 123, 764-789.

Luhrmann M (2010) Consumer expenditures and home production at retirement - new evidence from Germany. German Economic Review 11, 225-245.

Mastrobuoni G (2009) Labor supply effects of the recent social security benefit cuts: empirical estimates using cohort discontinuities. Journal of Public Economics 93, 1224-1233.

McCrary J (2008) Manipulation of the running variable in the regression discontinuity design: a density test. Journal of Econometrics, 142, 698-714.

Moreau N and Stancanelli E (2015) Household consumption at retirement: a regression discontinuity study on French data. Annales d'Economie et Statistique 117/118, 253-276. 
Nagore Garcia A, Rossi M and Van Soest A (2021) Retirement of the self-employed in the Netherlands. Small Business Economics 56(1), 385-402.

Piccheo M and Van Ours JC (2019) The mental health effects of retirement. (IZA Discussion Paper Series No. 12791).

Pollak RA and Watcher ML (1975) The relevance of the household production function and its implications for the allocation of time. Journal of Political Economy 83, 255-277.

Rogerson R and Wallenius J (2016) Retirement, home production, and labor supply elasticities. Journal of Monetary Economics 78, 23-34.

Rogerson R and Wallenius J (2019) Household time use among older couples: evidence and implications for labor supply parameters. Quarterly Journal of Economics 134(2), 1079-1120.

Schwerdt G (2005) Why does consumption fall at retirement? Evidence from Germany. Economics Letters 89, $300-305$.

Smith S (2006) The retirement consumption puzzle and involuntary retirement: evidence from the British Household Panel Survey. The Economic Journal 116, C130-C148.

Stancanelli E and Van Soest A (2012) Retirement and home production: a regression discontinuity approach. American Economic Review 102, 600-605.

Van Erp F, Vermeer N and van Vuuren D (2014) Non-financial determinants of retirement: a literature review. De Economist 162, 167-191.

Velarde M and Herrmann R (2014) How retirement changes consumption and household production of food: lessons from German time-use data. The Journal of the Economics of Aging 3, 1-10.

Vermeer N (2016) Age anchors and the expected retirement age: an experimental study. De Economist 164, $255-279$.

Vermeer N, Van Rooij M and Van Vuuren D (2019) Retirement age preferences: the role of social interactions and anchoring at the statutory retirement age. De Economist 167, 307-345.

Cite this article: Been J, Goudswaard K (2023). Intertemporal and intratemporal consumption smoothing at retirement: micro evidence from detailed spending and time use data. Journal of Pension Economics and Finance 22, 1-22. https:// doi.org/10.1017/S1474747221000330 